\title{
A COMPARISON OF LOCATION FACTORS EVALUATION IN THE SECONDARY AND TERTIARY SECTORS
}

\author{
Eliška Jirásková
}

\section{Introduction}

Assessment of location factors cannot be considered stable either from the point of view of time, or that of particular economic sectors. [4], [15], [17] However, it is possible to define economic sectors which can be considered as demanding a large amount of space in terms of location factors and economic sectors which are spatially neutral. Thanks to the significant instability in evaluation of localization factors a goal of this article is to find a possible conformity at least in an approach to the localization in individual examined economical branches. Proving this conformity could be helpful especially when processing competitiveness of a region and for attracting economical subjects of examined sectors. The examined sectors are only secondary and tertiary sectors because these sectors are considered as the main power of the economy nowadays.

The first part of the paper describes the theoretical background related to localization of industry and services, proceding from the oldest theories to the latest ones. Furthermore, attention is paid to the most important location factors which influence economic entities. Since the data are based on primary research, more attention is focused on the research course. The selection of respondents is explained, followed by their characteristics and the process of the data collection. Finally, the following hypothesis is verified by means of regression analysis:

The evaluation of particular factors by industrial entities and service entities can be considered identical.

\section{Theoretical Background to Assess the Location Theories}

From the point of view of location factors it can be stated that theories specific to particular sectors were the first to emerge during the 19th and at the beginning of the 20th century. At first, they focused on agriculture [41] and next on industry [33], [35], [22] and services [13]. Localization theory itself started to take shape during the first industrial revolution when the primary purpose in the process of locating an industrial plant was the maximum reduction in transport costs. The location factor of Alfred Weber [42] is considered the most important work on industry and a creator of a comprehensive classical theory. This theory assumes that entrepreneurs decide to locate their plants in such places where they have the lowest production costs, but the concept presented by reducing distances cannot be, because of globalization, considered as fully valid at this time.

Weber's work concerning industrial location factors was further developed for example by Engländer [7] who emphasized the factor of goods demand and goods supply or by Edgar Hoover (1948) who sought to find higher profit in the localization process in "connecting" industrial plants to basic production activities of a particular geographic area. Yet these two theories are thought to be current. The demand and interconnection of production activities in one area can, at present, be seen especially in large industrial enterprises. As an example, the automotive industry could be mentioned. Conversely, there could be registered a decrease in the importance of Weber's microeconomic criteria, which are resources at labour market. [14]

Another important milestone in industrial location factors was the opening of economies. Reduction of transport costs, globalizing environment and structural changes of economy from the primary sector to the secondary and subsequently to the tertiary sector are related to the change of the importance of the particular 
location factors and to the change of space costs. The theory known as sector base theory is based on these development changes in the composition of economic activities. This theory shows that primary sector growth is typical for the first stage of the region's development and is followed by the growth of the manufacturing industry. Not only does this cause growth in production, but also workforce productivity and workforce migration, which leads in turn to changes in workforce and capital allocation and to a transfer of these production factors from one economic sector to another one. Unemployment in the tertiary, or eventually in the quaternary sectors may become a criterion of the level of development of the region in question.

For this reason, it is not possible to consider the approach to industry location factors as identical to the approach to service location factors. The central place theory (CPT) by Christaller [13] is regarded as the most important service location theory. It explains spatial organization of the economy as a whole. A simplified premise of this theory is an area where there are no natural or other barriers. Even though Christaller's ideal model, where clients and company owners behave rationally and where natural resources as well as consumers are equally distributed in space, does not exist in reality, this theory has its practical importance and it is used, for example, by Mori, Nishikimi and Smith [29] for industry location factors. Sombart (1934) also dealt with service location factors. In his theory, he divided cities into two basic groups of internally oriented and externally oriented cities. The first group focuses on providing services especially to their own residents. The production of externally oriented cities focuses not only on their own residents, but also on services provided for their surroundings. According to Coffey and Polèse, [3] there are three main factors of service localization:

- a highly skilled workforce;

- additional services;

- costs related to delivery to the market.

Dunning [6] and Krugman [20] with their new economic geography belong to the representatives of the newer location theories. This theory has been developed by several other economists and geographers. [9], [25] Unfortunately, the new economic geography is not able to explain where particular industries will occur and why they occur in some specific areas more often than in some others. This issue is the subject of many studies primarily on the regional basis. Furthermore, there appears an effort to explain the localization placement process regardless of the economic sector.

\subsection{Theoretical Bases of Location Factors}

A location factor means cost economies carried out by a company due to appropriate spatial perception and it is thus seen as a competitive advantage. The fundamental aim of location theories is to define location factors and, given the rational behaviour of economic entities, to determine their optimal space distribution. Decision-making is, however, often based on routine decisions rather than on rational decisions and the behaviour of economic entities is not always based on profit maximalization. [30] A major reason for choosing the socalled satisfactory variant is also the fact that traditional location factors (transport and workforce costs) are constantly losing their importance and their influence on localization decision-making is weakening significantly. [27]

There is no general overview of location factors classification. For example the concept of location factors classification is their division into soft and hard is at this time often used. Hard factors are those which influence regional dispositions for a particular economic activity and they also have a direct impact on the net profit of a particular economic entity. Soft factors in the scope of this theory are those whose impact on economic outputs is not directly measurable, which means that they do not accrue in the accounts. [34] These factors have recently become increasingly significant and they are attributed to the increasing importance of the process of localization choice. [42] The main advantage of these factors is that they get closer to current trends in economic development. On the other hand, their main disadvantage is the fact that it is very difficult and sometimes nearly impossible to measure them.

Since there are many approaches to localization the list of classification from which the final selection came is due to better clarity categorized in Tab. 1. 


\section{Tab. 1: The typology of localization factors}

\begin{tabular}{l|l|l}
\multicolumn{1}{c|}{ Author } & \multicolumn{1}{c|}{ Type of LF } & \multicolumn{1}{c}{ Examples of LF } \\
\hline Ponikelský [32] & General & Location, infrastructure, environment \\
\hline Starzycná [36] & General & Ditto as Ponikelský + human resources, brownfields. \\
\hline Wokoun [43] & $\begin{array}{l}\text { Regional } \\
\text { development }\end{array}$ & $\begin{array}{l}\text { Ditto as Starzycná + intangible factors, Residential } \\
\text { Structure }\end{array}$ \\
\hline Grabow a Hollbach- & & The soft could be important without becoming hard ones. \\
\cline { 3 - 3 } Grömig [10] & \multirow{2}{*}{$\begin{array}{l}\text { Soft business and } \\
\text { individual and hard } \\
\text { transport infrastructure. }\end{array}$} \\
\cline { 3 - 3 } & $\begin{array}{l}\text { Soft business - are immeasurable, because they depend } \\
\text { on a subjective evaluation of the businessman. }\end{array}$ \\
\cline { 3 - 3 } & $\begin{array}{l}\text { Soft individual - matter of personal preferences } \\
\text { of management and employees. }\end{array}$ \\
\hline Own summary & International & $\begin{array}{l}\text { Political-economic environment, exchange rate regime, } \\
\text { social empathy, favoured credit terms. }\end{array}$ \\
\hline Lösch [23] & Macroeconomic & Market size, transport costs. \\
\hline Viturka [39] & Microeconomic & $\begin{array}{l}\text { Market, technological, regulatory, competitive } \\
\text { and geographical. }\end{array}$ \\
\hline
\end{tabular}

Source: own

26 current location factors been examined in the scope of empirical research. These factors were selected from different types of groups in which it was possible to presume some importance in the scope of examined economical entities. The selection of the examined localization factors was based on literature research and to a final selection the factors which suppose to have the biggest influence on not only economical subjects but even more on economical subjects in a industrial sector and in services were chosen.

For greater clarity, selected factors were divided into 4 groups. In these groups, individual factors can be further divided into several subgroups. In general, microeconomic location factors are primarily concern. However, some attention is paid to some macroeconomic factors because of their complexity and presumed influence. For greater clarity, the examined factors were recorded into a clearly arranged diagram, see Tab. 2.

\section{Empirical Research Methodology of Location Factors for Small and Medium Enterprises}

The examined location factors were chosen on the basis of a review of literature, with particular emphasis being placed on the important location factors of small and medium-sized enterprises based in the Czech Republic. [16], [19] The primary sector was completely eliminated from the examination, as it is not influenced by the examined factors and it is very complicated to reach selected respondents. Another reason not to include the primary sector in the research is the reduction of the share of agricultural activities in GDP, especially in favour of the tertiary sector. In the research there were included 13 economic sections with the following characteristics:

- the factors that are affecting them;

- the possibilities to reach them;

- the decisions for their localization.

The sorting of the research features was conducted according to the classification CZ-NACE and for the final research there were selected 13 sections, of which a total of 455 companies were addressed with the questionnaire. There was no expectation of $100 \%$ interest in the questionnaires. Thus in each section, 35 small and medium sized companies were responded, out of which $22 \%$ were from the secondary and $78 \%$ from the tertiary sector. This corresponds roughly with the share of GDP in the Czech Republic because in 2010 the service sector participated 


Soft
Tradition and history of the site
Quality and attractiveness of the area
City background
Availability of information and communication
technology
Economic situation of the region
Image of the region
Leisure opportunities
Cooperation with state administration
Quality of job centres
Presence of foreign companies
Availability and quality of research centres

\section{Regional and local}

\begin{tabular}{ll|l|l}
\hline \multicolumn{3}{c}{ Business } \\
\hline $\begin{array}{l}\text { Geographical proximity } \\
\text { - of clients } \\
\text { - of competing companies } \\
\text { - of suppliers }\end{array}$ & $\begin{array}{l}\text { Other } \\
\text { Availability of additional services } \\
\text { Possible cooperation with competing enter- } \\
\text { prises } \\
\text { Proximity plants belonging to the same } \\
\text { company }\end{array}$ \\
\hline Soft & \multicolumn{1}{c}{ Hard non-cost } & Hard cost-related \\
Mentality of the staff & $\begin{array}{l}\text { Availability of qualified human } \\
\text { resources }\end{array}$ & Workforce cost \\
\hline \multicolumn{4}{c}{ Infrastructural } \\
\hline Non-cost & Cost-related \\
State of transport infrastructure & Shipping costs \\
\hline
\end{tabular}

Level of taxes and fees

Availability of office and non-residential

premises

Prices of areas and buildings

Environmental requirements, conditions and standards in the creation of GDP with about $61 \%$. [5] So we can see a clear dominance of the tertiary sector. [12] It could be said that in the Czech Republic there are generally fewer industrial companies than services and because the respondents were selected by random sampling, the primary goal was not the equal representation of both sectors. As it was said previously, 13 economic sectors were ranked into the research. The following 3 sections of the industry sector were addressed:

- water supply, services connected to wastewater and waste processing and remediation;

- manufacturing;

- construction.
The following 10 sections of the service sector were addressed:

- administrative and supportive activities;

- transport and storage;

- information and communication activities;

- real estate activities;

- other activities;

- finance and insurance;

- professional, scientific and technical activities;

- accommodation, catering and hospitality industry;

- wholesale and retail business;

- education.

The changing industrial structure of the economy can be considered as one of the drives 
of the competitiveness in the region. According to Viturka [40], the explanatory power of the existing studies on the impact of the sector structure of the state in the region is only partial. It is not possible to confirm that the services are usually less concentrated than the industry. [37], [45] The processes of the changes in economy lead to the changes in the workforce, capital allocation and to the transfer of the production factors from one sector to another. The paper also summarizes which location factors play the biggest role in the location of services in particular and which others are important for industrial production enterprises.

Questionnaires were chosen as the most appropriate technique for conducting empirical research in the scope of the research described. First of all questionnaires were sent electronically to respondents. The contacted respondents were asked which of the above mentioned location factors are important for their localization, in relation to the type of their economic activity. Due to the small number of questionnaires which were returned, frequent e-mail delivery failures and occasional lack of electronic communication, the electronic survey was completed by phone interviews. A scale of 1 to 5 points was chosen for the questionnaire inquiry (with 1 point equalling absolutely unimportant, 2 = rather unimportant, $3=$ neither important, nor unimportant, $4=$ rather important, $5=$ absolutely important), and the so-called zero point was also taken into account. This method of questioning allowed easier processing of the results obtained.

\section{Importance of the Examined Factors in Terms of Sectors}

There are a number of studies focused on location factors of industrial enterprises. [21], [28] Due to fatal consequences associated with a failure in localization of industrial enterprises and with significant costs connected with eventual change of location, it was assumed that greater importance of individual location factors will be proved in secondary sector enterprises. This assumption was confirmed, as half of the examined factors was evaluated as more important in industrial enterprises. Unlike the tertiary sector enterprises, the industrial enterprises put more emphasis especially on the following criteria:

- tradition and history of the site;

- availability and quality of research centres;
- cooperation with state administration;

- quality of job centres;

- level of taxes and fees;

- environmental requirements, conditions and standards;

- geographic proximity of suppliers;

- availability of additional services;

- possible cooperation with competing enterprises;

- proximity of a plant belonging to the same company;

- qualified human resources;

- state of transport infrastructure;

- shipping costs.

Based on the research results, we may also define four location factors which do not play a significant role in case of industrial enterprises and which are taken into account only in the location process of economic entities providing their clients with services. These include:

- availability of information and communication technology;

- image of the region;

- leisure opportunities;

- workforce cost.

\section{Verification of Assessment Conformity}

Simple linear regression was used to describe dependencies among individual sectors. The mutual dependence of the assessment of location factors of the enterprises belonging to the secondary and the tertiary sectors was assessed due to the above mentioned simple linear regression. The initial regression model was the usual form (1) for which the variable $Y$ equals to factor assessment by tertiary sector enterprises, $X$ to factor assessment by secondary sector enterprises, $\beta_{1}$ corresponded to direction and regression quotient expressing dependence of the change of value of $Y$ in case $X$ is changes, $\beta_{0}$ absolute parameter or quotient and the last part of it is a random variable.

$$
Y=\beta_{0}+\beta_{1} X+\varepsilon
$$

The following hypotheses were tested in the first stage:

$\mathrm{H}_{0}$ : The selected functional relationship between dependent and independent variable does not exist.

$\mathrm{H}_{1}$ : The selected functional relationship between dependent and independent variable exists. The statistical importance of individual 
regression parameters was also tested. In particular it concerns the verification of the importance of direction and quotient. Given that the hypothesis claiming that it is possible to consider the $\beta_{0}$ quotient to be statistically unimportant was verified at the $5 \%$ significance level, then it is possible to modify the regression model to the form (2):

$$
Y=\beta_{1} X+\varepsilon
$$

and to verify again the following hypothesis, based on the equation without a constant:

$\mathrm{H}_{0}$ : The selected functional relationship between dependent and independent variable does not exist.

$\mathrm{H}_{1}$ : The selected functional relationship between dependent and independent variable exists.

This is followed by the hypothesis on statistical importance of the direction of the $\beta_{1}$ parameter and the hypothesis concerning assessment conformity between enterprises belonging to individual sectors was tested in the final stage, given that if it is possible to consider individual assessments to be identical, null hypothesis rejection must not occur.

In case of statistical importance of individual parameters, it is possible to define the region of acceptance as $W(3)$ with the test criterion $T(4)$.

$$
\begin{aligned}
& \mathrm{W}=\left\{\mathrm{T}:|\mathrm{T}| \geq \mathrm{t}_{1-\frac{\alpha}{2}}(\mathrm{n}-1)\right\} \\
& \mathrm{T}=\frac{b-\beta}{s} * \sqrt{\sum x_{\mathrm{i}}{ }^{2}}
\end{aligned}
$$

If the test criterion is not included in the region of acceptance, we do not reject the null hypothesis and the assumption that $\beta_{1}=1$ has been confirmed and individual assessments may be considered to be identical in the scope of both examined sectors.

For greater clarity, the conformity assessment of both examined sectors will be described for working factors only, hypotheses

\begin{tabular}{|c|c|c|c|c|c|}
\hline \multirow[t]{2}{*}{ Tab. 3: } & \multicolumn{5}{|c|}{$\begin{array}{l}\text { Regression analysis for the group of working location factors in the model } \\
\text { with a constant }\end{array}$} \\
\hline & Parameter & Estimation & $\begin{array}{c}\text { Test } \\
\text { criterion } \mathrm{T}\end{array}$ & $\begin{array}{l}\text { Critical } \\
\text { region }\end{array}$ & P-Value \\
\hline Paramet & r $\beta 1$ : b1 estimation & 1.162 & 22.422 & 2.770 & 0.000 \\
\hline \multirow{2}{*}{\multicolumn{2}{|c|}{ Parameter $\beta 0$ : b0 estimation }} & -7.375 & -2.738 & 2.770 & 0.052 \\
\hline & & $\begin{array}{l}\text { Test } \\
\text { criterion } \mathrm{F}\end{array}$ & $\begin{array}{l}\text { Critical } \\
\text { region W }\end{array}$ & P-Value & \\
\hline \multicolumn{2}{|c|}{ Variance analysis } & 502.77 & 7.71 & 0.000 & \\
\hline
\end{tabular}
having been verified analogically also for the other three groups of factors.

Source: own

Tab. 3 shows the existence of a functional dependency between dependent and independent variables, as for variance analysis the $\mathrm{P}$-Value $=0.000$ and the critical region $\mathrm{W}$ $=\{F: F \geq F(1.4)=>502.77 \geq 7.71)$. We can therefore reject the $\mathrm{H}_{0}$ hypothesis: The selected functional relationship between dependent and independent variable does not exist, and at the same time, we do accept $\mathrm{H}_{1}$ hypothesis: The selected functional relationship between dependent and independent variable exists.

The statistical importance of individual regression parameters was also tested, and its results allow us to state that, unlike the $\beta_{1}$ parameter, the $\beta_{0}$ parameter is not statistically important and the regression function can thus be transformed into the model without a constant and the tested hypotheses for this model may be repeated, see Table 3 .

The values listed in Tab. 4 for the variance analysis show that we reject the $\mathrm{H}_{0}$ hypothesis and we do not reject the $\mathrm{H}_{1}$ hypothesis, and there is a statistically important relationship between the analysed variables. Tab. 4 also shows an evident statistical importance of the $\beta_{1}$ direction in the scope of which we reject the $\mathrm{H}_{0}$ hypothesis.

The last step to be made in order to verify conformity of individual assessments by means of the following hypothesis: 


\begin{tabular}{|c|c|c|c|c|c|}
\hline \multirow[t]{2}{*}{ Tab. 4: } & \multicolumn{5}{|c|}{$\begin{array}{l}\text { Regression analysis for the group of working location factors in the model } \\
\text { without a constant }\end{array}$} \\
\hline & b1 parameter & Estimation & $\begin{array}{c}\text { Test } \\
\text { criterion } \mathrm{T}\end{array}$ & Critical region & P-Value \\
\hline \multirow{2}{*}{\multicolumn{2}{|c|}{ Parameter $\beta 1$ : b1 estimation }} & 1.037 & 27.332 & 2.57 & 0 \\
\hline & & $\begin{array}{c}\text { Test } \\
\text { criterion } \mathbf{F}\end{array}$ & $\begin{array}{l}\text { Critical } \\
\text { region W }\end{array}$ & P-Value & \\
\hline \multicolumn{2}{|c|}{ Variance analysis } & 747.04 & 6.610 & 0 & \\
\hline
\end{tabular}

Source: own

$H_{0}: \beta_{1}=1$

$\mathrm{H}_{1}: \beta_{1} \neq 1$,

with the test criterion $\mathrm{T}$ :

$$
\mathrm{T}=\{(1.037-1) / 4.833\} * \sqrt{\sum x} 16203=0.996,
$$

and the critical region $\mathrm{W}=\left\{\mathrm{T}:|\mathrm{T}|=0.996 \geq \mathrm{t}_{1-\frac{\alpha}{2}}\right.$ $(5)=2.57\}$. As $T$ is not an element of $W$, we do not reject the $\mathrm{H}_{0}$ hypothesis and it is possible to consider the assessment of individual sectors to be identical in the scope of working factors. The same procedure was also applied to the other groups of factors, which show that enterprise assessments in the secondary sector and those in the tertiary sectors can be considered identical in terms of all groups of location factors. Figure 1 shows a graphical representation of the regression function for regional and local factors.

\section{Fig. 1: Regression fuction for regional and local factors}

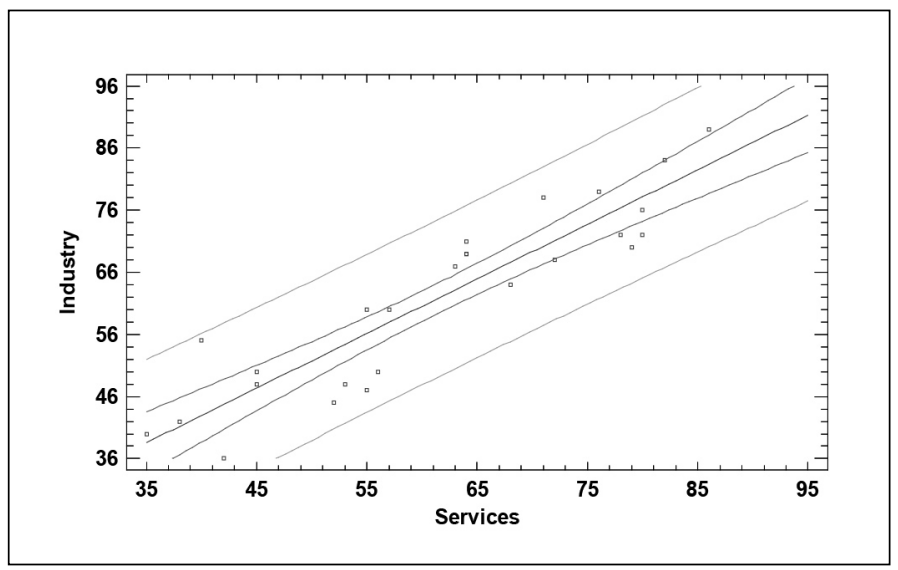

\section{Discussion}

Location factors cannot be taken as universal from perspective of individual sectors of the national economy. The research results prove an clear increase in the emphasis that is being placed on location factors in case of industrial enterprises whose costs associated to the change of localization are considerably higher that in the case of localization of services. Both sector may, nevertheless, expect the influence of the behaviour imitation of other economic entities. [1] In a case of services as well as in industry was found a sameness of the examined localization factors. Practically it means that even though localization factors are evaluated as more important by industrial enterprises from the view of the sectors of national economy is possible to consider the evaluation identical. The results of the research could be helpful in the preparation of a regional 
strategy of a development of the business environment in the regions of the Czech republic which could better accentuate factors influencing the choice of place of business of subjects which the region wants to attract in. It is clear that not only big industrial enterprises but also economical subjects providing services consider their localization.

Generally speaking, the location factors of industries and business services are largely influenced by modern technologies which have changed the importance of these location factors. Especially in the tertiary sector, the proximity to customers is not so important anymore [44] and, also, this factor can be now considered as consistently rated within the two studied sectors. It should also be noted that both sectors play the key role in the development of the region and in the regional economic growth, [8], [2], [11], [26] which often corresponds with the cultural dimensions, infrastructure [38] and other location factors.

Location theories constantly change, evolve and reveal new factors. Initial location theories aimed to reveal location factors which were important for agriculture. Another stage of the development of these theories was the development of industry and the change of perception of the need to choose appropriate localization connected to it. In terms of sectoral structural change to the national economy, the last change came with the rapid increase of the tertiary sector. Technological progress also has a major influence on the incessant development of location factors. Shipping costs may be cited as an example. Since Weber's times, their importance has been gradually decreasing in terms of their influence on localization-related decision-making. [24] It can be expected that further advance in perception of existing localization factors will take place in the future. Because of it this topic is considered as constantly actual and it is vital to continue to examine it and evaluate it. Besides long known localization factors it is important to consider new localization factors which form thanks to technological progress and to comparison of them in a long therm.

The change in the approach to localization is, of course, also caused by other external influences. Examples of this are the constantly changing business environment, increasingly open character of the market and changes in the behaviour of customers. Underestimating external influences and the localization stage may have fatal consequences for the future development of the given economic entity. Several recent studies confirmed the fact that a correct localization may be a determining factor for competitiveness of the given economic entity. [18]

\section{Conclusion}

The described research dealt with the evaluation of selected current location factors in the individual economical activities of the secondary and the tertiary sectors. The first part of this paper was focused on the review of location theories related to secondary and tertiary sector. From this review 26 location factor were chosen, divided into 4 groups regional and local factor, business factors, work-reletad and infrastructural factors - and examined. It was assumed that greater importance of individual location factors will be proved in secondary sector enteprises, due to the significant costs connected with the eventual change of location. This assumption was confirmed, because in term of average evaluation the industrial enterprises evaluated a half of examined particular factors as more important than the service enterprises did. Mainly it is:

- availability of additional services;

- possible cooperation with competing enterprises;

- qualified human resources;

- state of transport infrastructure;

- shipping costs.

Although some examined location factors can be considered as more important for industrial enterprises in term of average value after their summarization in the same topical groups, it is not possible to reject the hypothesis: The evaluation of particular factors by industrial entities and service entities can be considered identical. We can state that every individual evaluation can be considered as very similar in term of examined groups. Results can be considered proven, since about 450 survey respondents from the Czech Republic were selected by random selection with great feedback return questionnaires. A representation of individual enterprises corresponded with the structure of national economy of the Czech Republic.

The research shows that general understanding of local factors can be considerd 
as very close for the economic entity of the two biggest sectors of the national economy, in spite of the fact that everage value of individual examined factors indicate their bigger importance for industrial enterprises in the individual cases.

\section{References}

[1] BOSCHMA, R. A. and FRENKEN, K. Why is Economic Geography not an Evolutionary Science? Towards an evolutionary economic geography. Journal of Economic Geography. 2005, Vol. 6, Iss. 3, pp. 273-302. ISSN 14682710. doi:10.1093/jeg/lbi022.

[2] BOTER, H. SME perspectives on business support services: The role of company size, industry and location. Strategic Direction. 2006, Vol. 12, Iss. 2, pp. 244-258. ISSN 0258-0543. doi:org/10.1108/sd.2006.05622baf.007.

[3] COFFEY, W. J. and POLES, M. Producer Services and Regional Development: A policyoriented perspective. Regional Science. 1989, Vol. 67, Iss. 1, pp. 13-27. ISSN 1056-8190. doi:10.1111/j.1435-5597.1989.tb01179.x.

[4] DAMBORSKÝ, M. a WOKOUN, R. Lokalizační faktory malého a středního podnikání v podmínkách ekonomiky ČR. E+M Ekonomie a Management. 2010, Vol. 13, Iss. 2, pp. 32-43. ISSN 1212-3609.

[5] Databáze ročních národních účtů [online]. Praha: Český statistický úřad, 2011 [cit. 201201-29]. Available from: http://apl.czso.cz/pll/ rocenka/rocenka.indexnu.

[6] DUNNING, J. H. Location and the multinational enterprise: A neglected factor? Journal of International Business Studies. 1998, Vol. 29, Iss. 1, pp. 45-66. ISSN 00472506. doi:10.1057/palgrave.jibs.8490024.

[7] ENGLÄNDER, O. Theorie der Volkswirtschaft. Wien: J. Springer, 1930.

[8] FELDMAN, M. P. and FLORIDA, R. The geographic sources of innovation: Technological infrastructure and product innovation in the United States. Annals of the Association of American Geographers. 1994, Vol. 84, Iss. 2, pp. 210-229. ISSN 1467-8306. doi:10.1111/j.1467-8306.1994.tb01735.x.

[9] FUJITA, M., et al. The spatial economy: Cities, regions and international trade. Cambridge: MIT Press, 2001. ISBN 978-0262561471.

[10] GRABOW, B. and HOLLBACH-GROMIG, B. Weiche Standortfaktoren. Schriften des Deutschen Institut für Urbanistik Band, 89. Stuttgart-Berlin-Köln: Dt. Gemeindeverlag, 1995.
[11] HOFSTEDE, G. The business of international business is culture. International Business Review. 1994, Vol. 3, Iss. 1, pp. 1-14. ISSN 0969-5931.

[12] HOLUB, A. Strukturální odvětvové změny v procesu transformace české ekonomiky s ohledem na mezinárodní aspekty. Politická ekonomie. 1998, Vol. 46, Iss. 6, pp. 788-804. ISSN 0032-3233.

[13] CHRISTALleR, W. Central Places in Southern Germany. New Jersey: Prentice Hall, 1966.

[14] IVANIČKA, K. Úvod do ekonomickogeografického výskumu. 1. vyd. Bratislava: Slovenska akadémia vied, 1971.

[15] JEŽEK, J. Prostorová a regionální ekonomika. $1^{\text {st }}$ ed. Plzeň: Vydavatelství Západočeské univerzity, 1998. ISBN 80-7082-483-2.

[16] JIRÁSKOVÁ, E. Faktory lokalizace malých a středních podniků v České republice. $1^{\text {st }}$ ed. Liberec: Technická univerzita v Liberci, 2011. ISBN 978-80-7372-782-6.

[17] JIRÁSKOVÁ, E. Význam vybraných faktorü lokalizace pro malé a střední podniky. Liberec, 2013. 177 pp., 30 pp. app. Disertační práce (Ph.D.). Technická univerzita v Liberci, Ekonomická fakulta.

[18] KARAKAYA, F. and CANEL, C. Underlying dimensions of business location decisions. Industrial Management + Data Systems Competitiveness Review. 1998, Vol. 98, Iss. 7, pp. 321-329. ISSN 0263-5577. doi:10.1108/02635579810205395.

[19] KOLEKTIV autorů. Úvod do regionálních věd a veřejné správy. $4^{\text {th }}$ ed. PIzeň: Vydavatelství Aleš Čeněk, 2004. ISBN 80-86473-80-5.

[20] KRUGMAN, P. Increasing returns and economic geography. Journal of Political economy. 1990, Vol. 99, Iss. 3, pp. 483-499. ISSN 0022-3808. doi:10.1086/261763.

[21] KUPKE, V. and PEARCE, J. Changing industrial location and site preferences for small business: a south Australian case study. In: Pacific-Rim Real Estate Society Fourth Annual Conference. Perth: Western Australia, 1998.

[22] LAUNHARDT, W. Mathematische Begrüdung der Volkswirtschaftslehre, Leipzig, 1885.

[23] LÖSCH, A. The Economics of Location. $7^{\text {th }}$ ed. USA: The Murray Printing Company, 1978. ISBN 0-300-00727-2.

[24] MALECKI, E. J. Telecommunications technology and American rural development in the $21^{\text {th }}$ century. OTA Follow up conference report. Kentucky: University of Kentucky, 1996. 
[25] MARTIN, R. The new „geographical turn“ in economics: some critical reflections. Cambridge Journal of Economics. 1999, Vol. 23, Iss. 1, pp. 65-91. ISSN 1464-3545. doi:10.1093/ cje/23.1.65.

[26] MASKELL, P. Towards a knowledge-based theory of the geographical cluster. Industrial and Corporate Change. 2001, Vol. 10, Iss. 4, pp. 921-943. ISSN 1464-3650. doi:10.1093/ icc/10.4.921.

[27] MATOUŠKOVÁ, Z., et al. Regionální a municipální ekonomika. Praha: VŠE, 2000. ISBN 80-245-0052-3.

[28] MAZZAROL, T. and CHOO, S. A study of the factors influencing the operating location decisions of small firms. [online]. Property management. 2003, Vol. 21, Iss. 2 [cit. 201209-15], pp. 190-208. Available from: http:// search.proquest.com/docview/213302163/ abstract $/ 1396210 \mathrm{C} 8 \mathrm{BC} 65 \mathrm{~B} 3 \mathrm{E} 01 \mathrm{~F} / 27$ ?accountid= 17116. doi.org/10.1108/02637470310478918.

[29] MORI, T., NISHIKIMI, K. and SMITH, E. T.The Number-Average Size Rule: A New Empirical Relationship Between Industrial Location and City Size. Journal of Regional Science. 2008, Vol. 48, Iss. 1, pp. 165-211. ISSN 0022-4146. doi:10.1111/j.1467-9787.2008.00550.x.

[30] NELSON, R. R. and WINTER, S. G. An Evolutionary Theory of Economic Change. USA: Cambridge, 1982. ISBN 0-674-27228-5.

[31] Netherlands Economic Institute in cooperation with Ernst \& Young. New location factors for mobile investment in Europe. Brussels Luxembourg: Office for Official Publications of European Communities, 1993. ISBN 92-826-5859-7

[32] PONIKELSKÝ, P., KOŠTEJNOVÁ, Z. and KUPKA, V. Ekonomika municipalit a regionů [online]. Praha: VŠRR, 2008 [cit. 2011-08-19]. Available from: http://www.vsrr.cz/reg/kestazeni/ emr2.pdf.

[33] ROSCHER, W. Studien über Naturgesetze, welche den zweckmässigen Standort der Industriezweige bestimen. Heidelberg, 1865.

[34] RUMPEL, P., SLACH, O. and KOUTSKÝ, J. Měkké faktory regionálního rozvoje. $1^{\text {st }}$ ed. Ostrava: Repronis, 2008. ISBN 978-80-7368435-8.

[35] SCHÄFFLE, A. E. Das Gesellschaftliche System der menschlichen Wirtschaft. Tübingen, 1873.
[36] STARZYCZNÁ, H. Prostorová ekonomika. $1^{\text {st }}$ ed. Opava: Slezská univerzita v Opavě, 2007. ISBN 978-80-7248-439-3.

[37] VAŠÍČEK, B. Prostorová ekonomie a prostorové externality: Přehled teorie a empirická evidence. Politická ekonomie. 2008, Vol. 56, Iss. 5, pp. 684-708. ISSN 0032-3233.

[38] TÖTLING, F. and WANZENBÖCK, $H$. Regional differences in structural characteristics of start-ups. Entrepreneurship and Regional Development. 2003, Vol. 15, Iss. 4, pp. 351-370. ISSN 1464-5114. doi:10.1080/0898562032000 058923.

[39] VITURKA M., et al. Investiční atraktivita vybraných měst České republiky. $1^{\text {st }}$ ed. Brno: Vydavatelství MU, 1998. ISBN 80-210-2007-5.

[40] VITURKA, M. Konkurenceschopnost regionů a možnosti jejího hodnocení. Politická ekonomie. 2007, Vol. 55, Iss. 5, pp. 637-657. ISSN 0032-3233.

[41] von THÜNEN, J. H. Der Isolierte Staat in Beziehung auf Landwirtschaft und Nationalökonomie. Hamburg: Puthes, 1826.

[42] WEBER, A. Theory of the Location of Industrie. University of Chicago, 1969.

[43] WOKOUN, R. Regionální konkurenceschopnost a faktory regionálního rozvoje $\mathrm{v}$ ČR. In: KLíMOVÁ, V. (Ed.). Sborník př́spěvků z XI. mezinárodního kolokvia o regionálních vědách 2008. $1^{\text {st }}$ ed. Brno: Masarykova univerzita, 2008. pp. 24-32. ISBN 978-80-210-4625-2.

[44] ZAHEER, S., LAMIN, A. and SUBRAMANI, M. Cluster capabilities or ethnic ties? Location choice by foreign and domestic entrants in the services offshoring industry in India. Journal of International Business Studies. 2009, Vol. 40, Iss. 6, pp. 944-968. ISSN 0047-2506. doi:10.1057/jibs.2008.91.

[45] ŽlŽKA, M. Služby v kontextu podnikatelského prostředí České republiky. $E+M$ Ekonomie a Management. 2012, Vol. 15, Iss. 4, pp. 97-109. ISSN 1212-3609.

Ing. Eliška Jirásková, Ph.D.

Technical University of Liberec

Faculty of Economics

Department of Business Economy and Management eliska.jiraskova@tul.cz 


\section{Abstract}

\section{A COMPARISON OF LOCATION FACTORS EVALUATION IN THE SECONDARY ANDTERTIARY SECTORS}

\section{Eliška Jirásková}

The paper deals with the evaluation of selected current location factors in the individual economical activities of the secondary and the tertiary sectors. These two sectors were chosen because of the increasing importance of appropriate localization and huge costs associated with its change. A review of literature on location theories related to both examined sectors is carried out in the first part of the paper. In the scope of this review, a brief description of location factors can be found. It is followed by a diagram of chosen location factors. 26 factors were divided into four groups - local, business, workforce and infrastructural factors. This classification is used for a better and clearer understanding of the chosen factors. The following part of the paper contains a description of the research methodology, including the appropriate choice of investigative method and a detailed characteristics of chosen respondents. As well as the primary sector, large enterprises were eliminated, as focusing described research to very small, small and medium-sized enterprises is much easier and, in case of SME, it is also possible to presume a stronger emphasis placed on the location factors under examination.

The aim of the paper is to verify by means of regression analysis whether the assessment of both sectors can be considered identical. This hypothesis was confirmed in all examined groups and therefore it is not possible to presume a different perception of location factors in the case of industrial enterprises in comparison to enterprises providing services.

Key Words: Location factors, regresion analysis, secondary and tertiary sector.

JEL Classification: C12, R10, R53.

DOI: 10.15240/tul/001/2015-1-004 